\title{
Can Artificially Designed Protein Combat Cancer?
}

\section{Bivas Nag1, Kanagavalli Mathivathanan'2, Debraj Mukhopadhyay ${ }^{3}$ and Dattatreya Mukherjee ${ }^{4 *}$}

${ }^{1}$ Student and Under Graduate Research Scholar, Department of Life science and Biochemistry, St. Xavier's College (Autonomous), Mumbai, Maharashtra, India

${ }^{2}$ Assistant Professor, Department of Obstetrics and Gynecology, Maharshi Menhi Homeopathic Medical College, Katihar, Bihar, India

${ }^{3}$ Public Health Scholar, Department of Public Health, School of Allied Health Sciences, Delhi Pharmaceutical Sciences and Research University (DPSRU), New Delhi, India ${ }^{4}$ MBBS Student and Undergraduate Research Scholar, International School, Jinan University, Guangzhou, Guangdong, China

*Corresponding Author: Dattatreya Mukherjee, MBBS Student and Undergraduate Research Scholar, International School, Jinan University, Guangzhou, Guangdong, China.

Cell invokes a plethora of mechanisms to maintain its genomic integrity. When replication and transcription occur on the same strand, to lessen their collision probability, a genome-wide bias prevails in gene distribution, so that, Replication and Transcription happen co-directionally [1,2]. But still, when such collisions take place, DDR components transiently remove RNAP from the template, to make room for the replication machinery to slide past the disputed region. Many factors help in the prevention of such collisions Gre proteins, Fob1 in Replication Fork Barrier site, FACT (chromatin remodeling), RECQL5 helicase, etc. [3].

But in precancerous and cancerous cells, where high replication stress prevails, due to mutation in the 553 gene or the DDR components malfunction, which may lead to, Double-Strand Breaks, due to replication run-off of upstream forks, or a fork may regress after a head-on collision, leading to endolytic cleavage of DNA by Ruv$\mathrm{ABC}$, etc. [4]. Recent studies show that mutations in genes responsible to prevent this type of collisions, give rise to cancer-prone conditions like Fanconi Anaemia, Ataxia-ocular apraxia type II, Amyotrophic lateral sclerosis type IV, etc. [5,6].

For a long time, cancer-therapeutic drugs are made to target various DDR components present especially in cancerous cells [7].
Received: May 28, 2021

Published: 00-00

(C) All rights are reserved by Dattatreya

Mukherjee.
But let's think the other way round can we utilize the high frequency of Replication-Transcription collision in cancerous cells and design a certain protein that can identify the collision sites and bind to and fuse both Transcription-Replication types of machinery, to irreversibly cause Replication Fork Stalling, the precancerous and cancerous cells will eventually get degraded as their genome will not replicate. The question here is If a protein can be devised, able to detect the collision sites and fuse the two types of machinery irreversibly, can division and metastasis of pre-/cancerous be prevented?

At the onset of collision, the cell synthesizes Fob1 protein to bind to the DNA sequence, present in between the soon-to-collide Replication-Transcription machinery, known as Replication Fork Barrier (RFB) site, to prevent a collision [8]. The Fob1 protein's gene sequence can be procured and can be used to incorporate our designer protein sequence in place of the Fob1 gene, using Group 2 Intron mediated gene replacement. so that whenever the cell generates the Fob1 synthesis signal, our Protein-X will be synthesized in place of Fob1. Using Bioinformatics tools, Protein-X should be designed in such a way, that it must have 2 specific domains to bind to the RNA polymerase and the DNA polymerases (like NtrC and 
other transcriptional factors), and form a bridge-like bond in between them, that is permanent. By this, the two colliding machineries will fuse, causing multiple irreversible fork stalls throughout the genome at the collision sites, ultimately causing failure in genome duplication. And thereby, cancer-prone cells will eventually degrade.

To summarise, the approval of the first cancer treatment was based on a targeted DDR inhibitor in a specified tumour-specific DDR-deficient context is likely only the beginning of what might be a key role for DDR-based drugs in future cancer therapy. Furthermore, the revolution in bioinformatics has opened up a slew of new possible cancer-fighting targets, but the viability of all of these approaches is still questionable.

\section{Acknowledgements}

Thanks to Editorial team of ACTA Scientific Pharmaceutical Sciences [ISSN: 2581-5423] for inviting us and giving us the opportunity to write on this topic.

\section{Author's Contribution}

Bivas Nag wrote the first draft. Dattatreya Mukherjee did the revisions and editing. Kanagavalli Mathivathanan and Debraj Mukhopdhyay did the final editing and all authors gave consent for the publication.

\section{Bibliography}

1. Sankar T S., et al. "The nature of mutations induced by replication-transcription collisions". Nature 535.7610 (2016): 178181.

2. Hoeijmakers J H J. "Genome maintenance mechanisms for preventing cancer". Nature 411.6835 (2001): 366-374.

3. García-Muse T and Aguilera A. "Transcription-replication conflicts: how they occur and how they are resolved". Nature Reviews Molecular Cell Biology 17.9 (2016): 553-563.

4. Gaillard H., et al. "Replication stress and cancer". Nature Reviews Cancer 15.5 (2015): 276-289.

5. Mohanty D. "Understanding complexity of Fanconi anaemia". Indian Journal of Medical Research 143.2 (2016): 132.
6. Tubbs A and Nussenzweig A. "Endogenous DNA Damage as a Source of Genomic Instability in Cancer". Cell 168.4 (2017): 644-656.

7. Lord C J and Ashworth A. "The DNA damage response and cancer therapy". Nature 481.7381 (2012): 287-294.

8. Puigvert J C., et al. "Targeting DNA repair, DNA metabolism and replication stress as anti-cancer strategies". FEBS Journal 283.2 (2015): 232-245.

\section{Assets from publication with us}

- Prompt Acknowledgement after receiving the article

- Thorough Double blinded peer review

- Rapid Publication

- Issue of Publication Certificate

- High visibility of your Published work

Website: www.actascientific.com/

Submit Article: www.actascientific.com/submission.php

Email us: editor@actascientific.com

Contact us: +919182824667 